TITLE:

\title{
Induced sputum concentrations of mucin in patients with asthma and chronic cough(Abstract_要旨 )
}

\author{
$\operatorname{AUTHOR}(\mathrm{S})$ : \\ Jinnai, Makiko
}

\section{CITATION:}

Jinnai, Makiko. Induced sputum concentrations of mucin in patients with asthma and chronic cough. 京都大学, 2010, 博士(医学)

ISSUE DATE:

2010-05-24

URL:

http://hdl.handle.net/2433/120920

RIGHT: 


\begin{tabular}{|c|l|c|c|c|}
\hline 京都大学 & 博士（医 学） & 氏 名 & 陣 内 牧 子 \\
\hline & \multicolumn{3}{l}{ Induced sputum concentrations of mucin in patients with asthma and }
\end{tabular}

論文題目 chronic cough

(喘息および慢性咳嗽患者における誘発喀痰中ムチン濃度の検討)

(論文内容の要旨)

気道の粘夜過分泌は、喘息をはじめとする種々の気道疾患における重要な病態生理学的 特徴の 1 つであり、喘息発作による死亡患者の剖検肺においては、しばしば過剩な分泌物 による気道閉塞が認められる。気道分泌物の主成分であるムチン（mucin）に関して、 Ordonez らは喘息患者の誘発喀痰上清中のムチン濃度を定量測定した。喀痰中ムチン濃 度は、中等症喘息患者 6 例において軽症喘息患者 7 例に比較して有意に高值を呈したの に対して、同時に病理学的に検討した気道杯細胞中の貯蔵ムチン量は両群で同等であった ことから、喘息の病態に杯細胞からのムチン分泌増加が関与している可能性を示唆した。 しかし喀痰中ムチン濃度測定の意義についての詳細は未だ不明である。また種々の疾患が 原因となる慢性咳嗽は臨床的に重要な問題であり、気道過分泌を訴える患者の存在や、病 理学的検討での杯細胞増生の存在が知られているが、喀痰中ムチン濃度に関する報告はな い。そこで喀痰上清中ムチン濃度を、喘息患者、咳喘息などの主要な原因疾患による慢性 咳嗽患者、健常者で比較検討し、臨床所見や生理学的所見との対比も行った。

高調食塩水のネブライザー吸入によって誘発した喀痰の上清中ムチン濃度を、 $17 \mathrm{Q} 2$ 抗体を用いてダブル-サンドイッチ ELISA 法にて測定した。既報に従い、患者の喀痰症状 の程度を「常に痰がある」、「時に痰がある」、「痰がない」の 3 群に分類した。慢性咳 嗽の原因疾患は日本呼吸器学会の「咳嗽に関するガイドライン」に基づいて診断した。

喘息 49 例、咳喘息 39 例、副鼻腔気管支症候群 9 例、胃食道逆流症 5 例、健常者 11 例 における喀痰中ムチン濃度は、各々 $674.8 \pm 548.8 \mu \mathrm{g} / \mathrm{ml} 、 350.4 \pm 374.0 \mu \mathrm{g} / \mathrm{ml} 、 638.4 \pm$ $650.7 \mu \mathrm{g} / \mathrm{ml} 、 134.3 \pm 93.1 \mu \mathrm{g} / \mathrm{ml} 、 212.0 \pm 167.1 \mu \mathrm{g} / \mathrm{ml}$ であり、喘息では健常者、咳喘息、 胃食道逆流症と比較して、また副鼻腔気管支症候群では健常者と比較して、それぞれ有意 に高值であった。喀痰症状は喘息、咳喘息、副鼻腔気管支症候群において顕著な傾向があ り、胃食道逆流患者と健常者では全例で痰の訴えはなかった。喀痰症状で分類した全患者 と健常者の計 4 群の比較では、「常に痰がある」患者では、「時に痰がある」、「痰がな い患者や健常者に比較して喀痰中ムチン濃度は有意に高かった。喘息患者に限った検討 では、喀痰中ムチン濃度は喀痰症状との間に上記と同様の関連を示し、喀痰中好酸球数と も正の相関を示したが、患者の年齢、罹病期間、重症度、スパイロメトリーで評価した肺 機能とは相関を示さなかった。しかしながら喀痰中ムチン濃度は、メサコリン気道感受性 や、スパイロメトリーよりも気道閉塞をより鋭敏に反映するとされる Impulse oscillometry system（IOS）の呼吸抵抗指標と負の相関を示した。喀痰症状の程度は何れ の臨床的・生理学的指標とも有意な相関を示さなかった。

誘発喀痰上清中ムチン濃度は、喘息患者、各種原因による慢性咳嗽患者、健常者におい て、主として喀痰量を反映して群間差を示した。喘息患者においては、ムチン濃度が気道 感受性や IOS の呼吸抵抗指標と負の相関を示したことから、ムチンが気道において防御 的な役割を果たしている可能性が示唆された。誘発喀痰上清中ムチン濃度の測定は、気道 疾患の病態解析に有用と考えられる。
（論文審査の結果の要旨）

気道の粘液過分泌は、種々の気道疾患における重要な病態生理学的特徴の 1 つである。杯細胞からのムチン分泌増加の喘息病態への関与が示唆されている が、喀痰中ムチン濃度測定の意義の詳細は不明である。また種々の疾患が原因 となる慢性咳嗽において喀痰中ムチン濃度に関する報告はみられない。そこ で誘発喀痰上清中ムチン濃度（以下ムチン濃度）を、典型的喘息患者、咳喘息 などの主要な原因疾患による慢性咳嗽患者、健常者において ELISA 法にて測定 し、群間比較、喀痰症状を含む臨床所見や生理学的所見との対比を行った。そ の結果、ムチン濃度は、健常者と比較して、典型的喘息、副鼻腔気管支症候群 で高值であったが、咳喘息、胃食道逆流症では増加を認めなかった。ムチン濃 度は喀痰症状と関連を認め、主として喀痰量を反映して群間差を示したと考え られた。また典型的喘息においてムチン濃度は、重症度やスパイロメトリー指 標と相関を示さなかったが、喀痰中好酸球数と有意な正の相関、また気道感受 性の強さ、呼吸抵抗指標と有意な負の相関を示した。従ってムチンが気道にお いて防御的な役割を果たしている可能性が示唆された。喀痰症状はこれらの指 標とは相関せず、ムチン濃度は喀痰症状よりも病態を反映していると考えられ た。以上より、気道疾患の病態解析におけるムチン濃度の測定の重要性が示唆 された。

以上の研究は、気道疾患の病態解明に貢献し、治療の発展に寄与するところ が多い。

したがって、本論文は博士（医学）の学位論文として価値あるもの と認める。

なお、本学位授与申請者は、平成 22 年 4 月 2 日実施の論文内容とそれ に関連した試問を受け、合格と認められたものである。 